\title{
HOW TO DO BUSINESS IN THE BALTICS - FOCUS ON LITHUANIA
}

Mantas Zalatorius

Swedish Trade Counsil

Lithuania

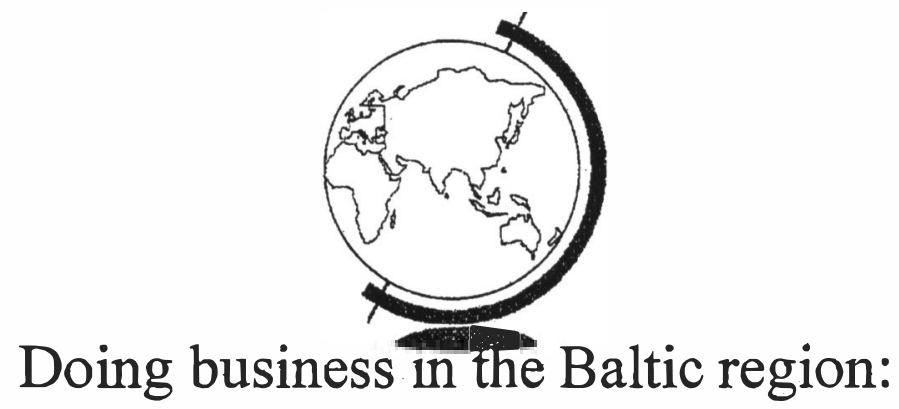

Lithuania in focus

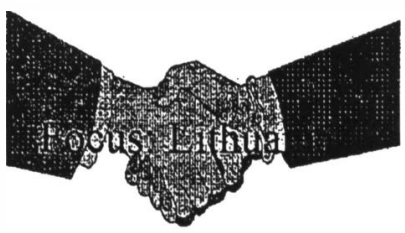




\section{What we are going to talk about?}

$\downarrow$ Who is talking to you?

$\downarrow$ The business environment in the Baltic countries

- Economical aspects

- Mental aspects

+ The tools whitch are good to use for succesfull bussines

$\downarrow$ Questions

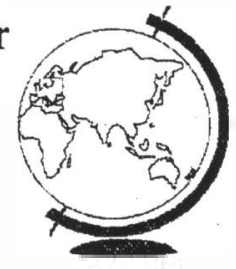

\section{SWEDISH TRADE COUNCIL Vilnius office}

$\downarrow$ Five years in Lithuania

+ Swedish, Lithuanian, English and Russian speeking office

+ TWO SIDES OF Swedish Trade Council

- Business information (Exportservice)

- Business development

+ Offices in Estonia, Latvia, Lithuania Poland, Russia, Check Republick, Slovakia, Hungary and Bosnia

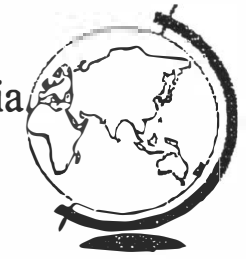




\section{What can STC Vilnius do for you?}

+ Providing information on doing business in Lithuania.

+ Signposting: provide guidance on establishing operations in Lithuania

+ Matchmaking: help provide suitable Lithuanian partners

+ Sourcing: help source components and products in Lithuania

$\downarrow$ Recruitment and head hunting

+ Provide one-stop-shopping for Swedish compinies

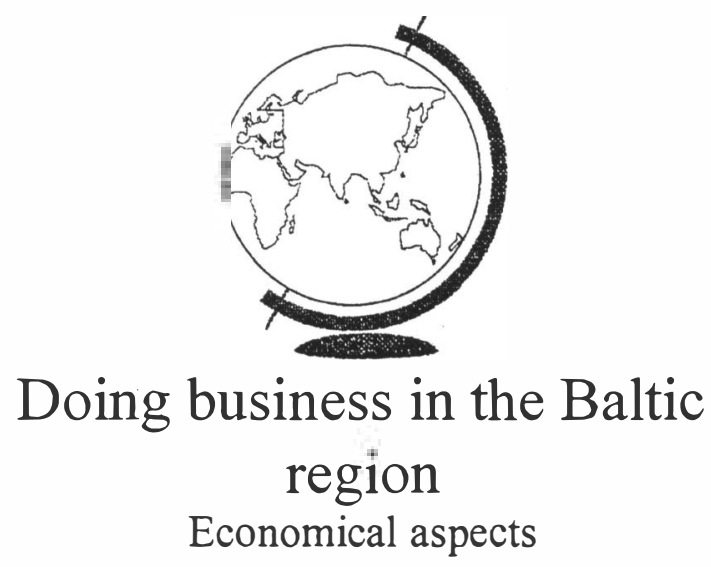




\section{Economical indicators}

+ GDP

+ GDP growth

+ Inflation

$\downarrow$ Purchasing power

+ Salary level etc.

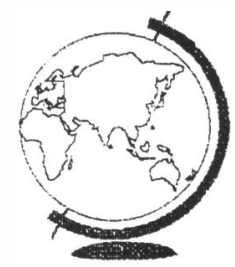

\section{GDP Growth (\%)}

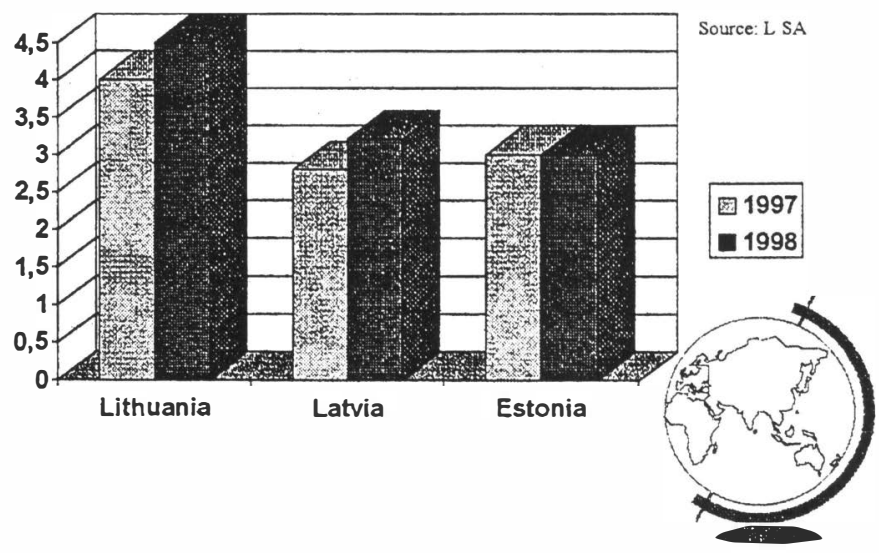




\section{Inflation}

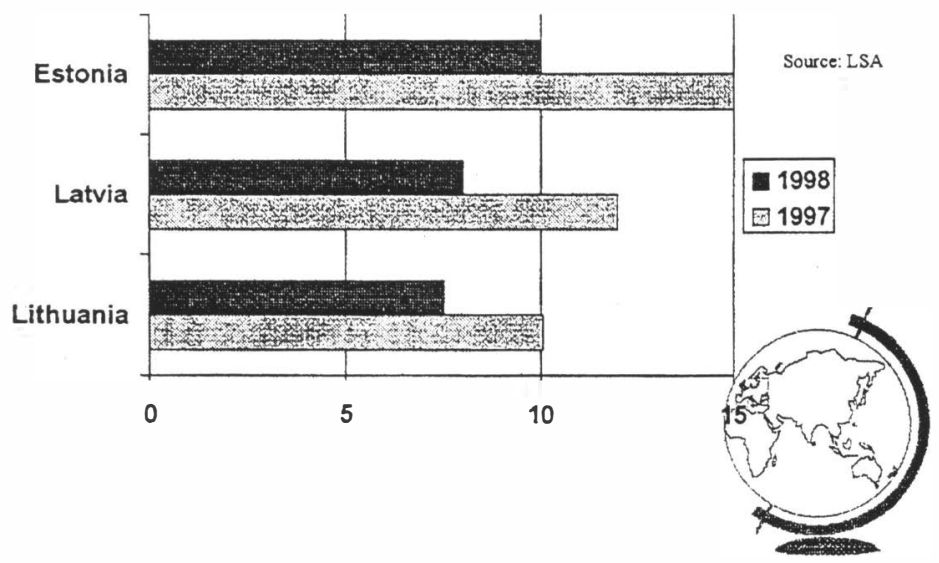

\section{Trade Deficit as Percentage of GDP}

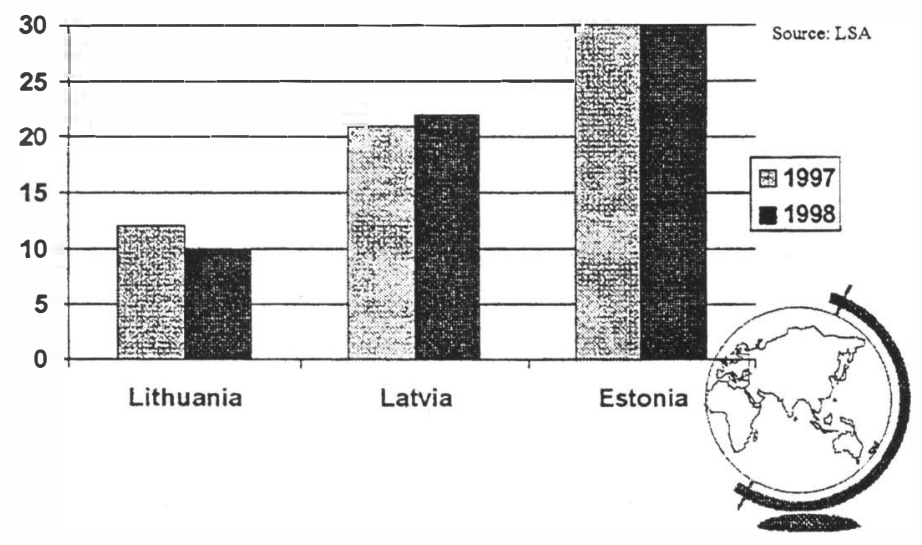




\section{Lithuanian GDP is the Largest in the Region}

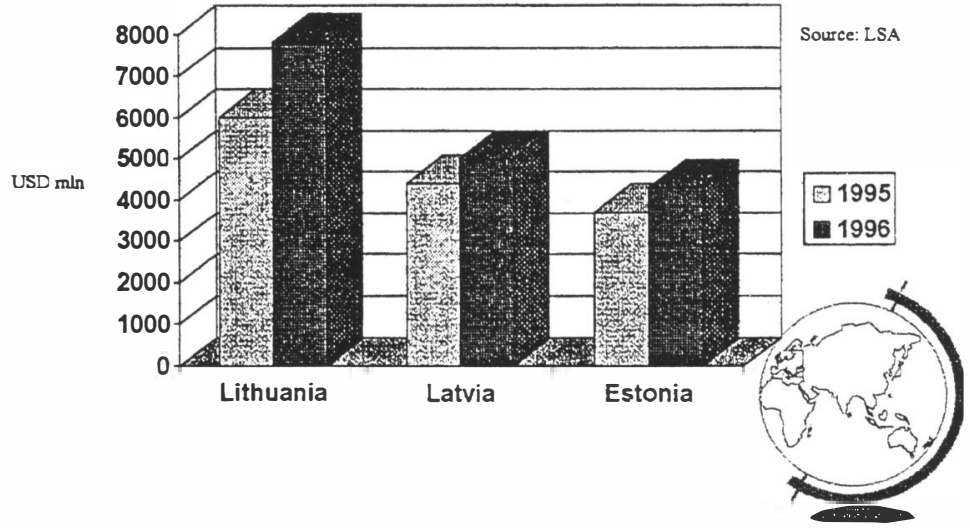

\section{GDP per capita in the region}

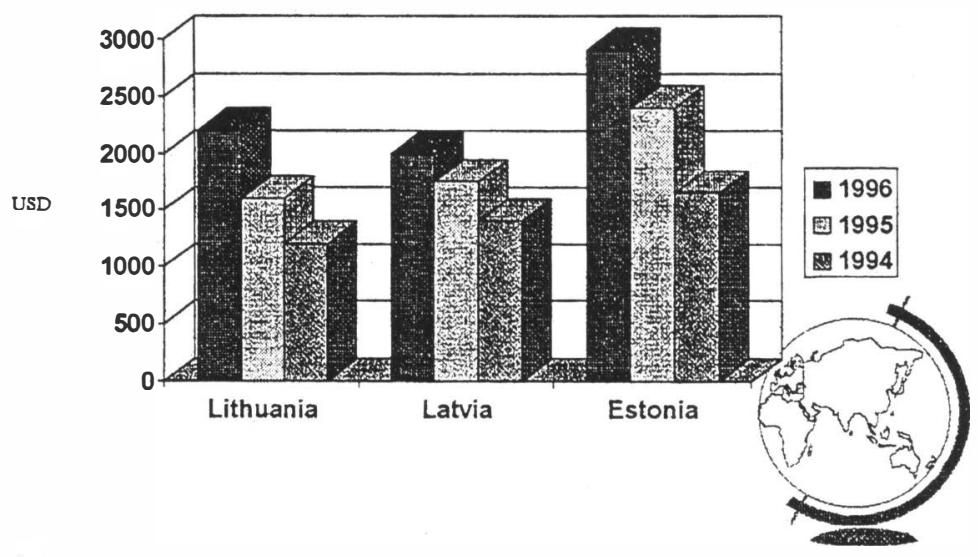




\section{GDP per capita in Purchasing power parities}

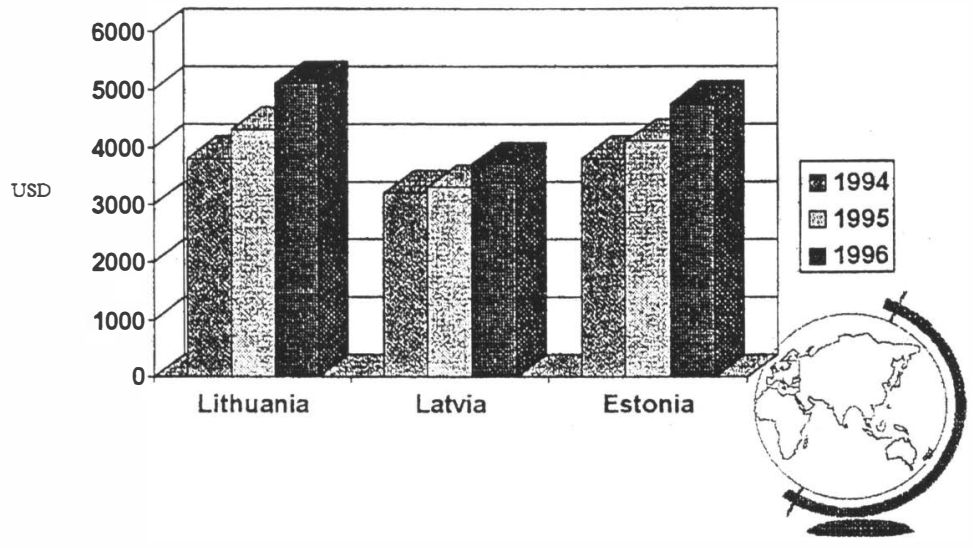

\section{Labour costs in the region}

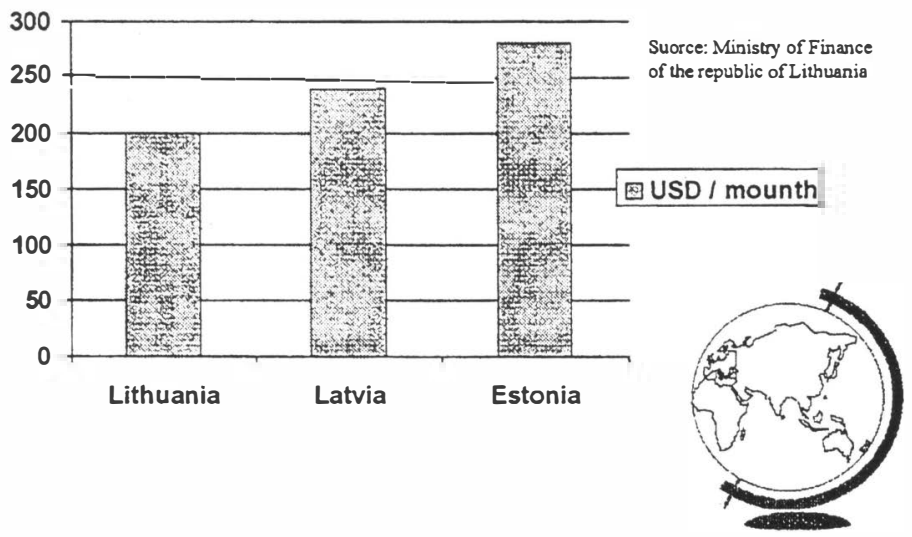




\section{The economical aspects of business environment are more or less common for all Baltic countries}

+ GDP grouth : $3-4 \%$

+ GDP per capita: 200 - 270 USD

+ Inflation: 10 - $15 \%$

+ Workforce: 200 - 300 USD

+ Trade ballance: negative in all countries

\section{Good reasons to start up and invest}

$\downarrow$ Rapid and positive pace of reforms

+ No minority problems

+ Well educated and not expencive workforce

$\uparrow 7,5$ million inhabitants in the reagion

+ Stabile and convertible currency

+ Strategic location: gateway to Russian market

+ Exellent transport inftastructure

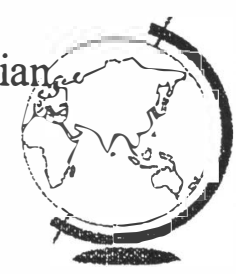




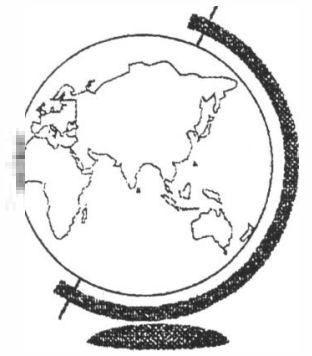 \\ Baltic countries is ONE REGION economically}

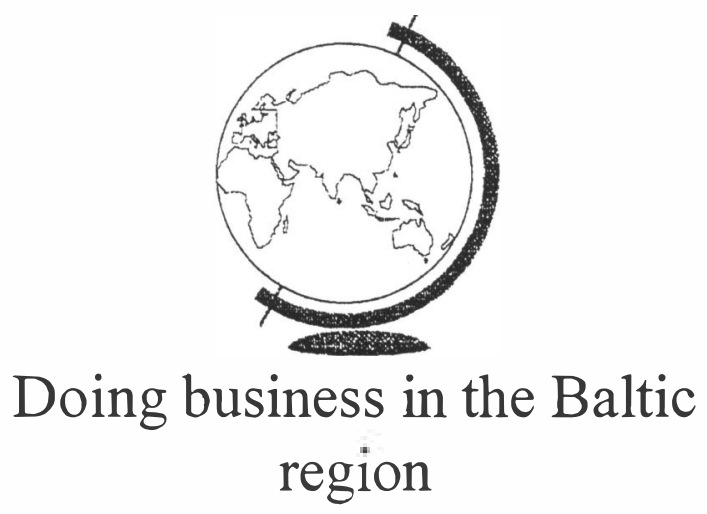

Mental aspects 


\section{Factors, whitch are forming the mentality of the nation}

+ History

+ Religion

+ Geographic position

+ Language

\section{Mentality factors are different}

$\begin{array}{llll} & \text { Lithunit } & \text { Latis } & \text { Estonia } \\ \text { Language } & \text { NO } & \text { NO } & \text { NO } \\ \text { Religion } & \text { NO } & \text { YES } & \text { YES } \\ \text { History }(1200-1940) & \text { NO } & \text { NO } & \text { NO } \\ \text { History }(1940-1991) & \text { YES } & \text { YES } & \text { YES }\end{array}$

Geografic position YES YES YES 


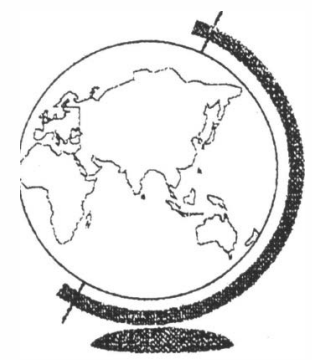

\section{Is it the one region mentally?}

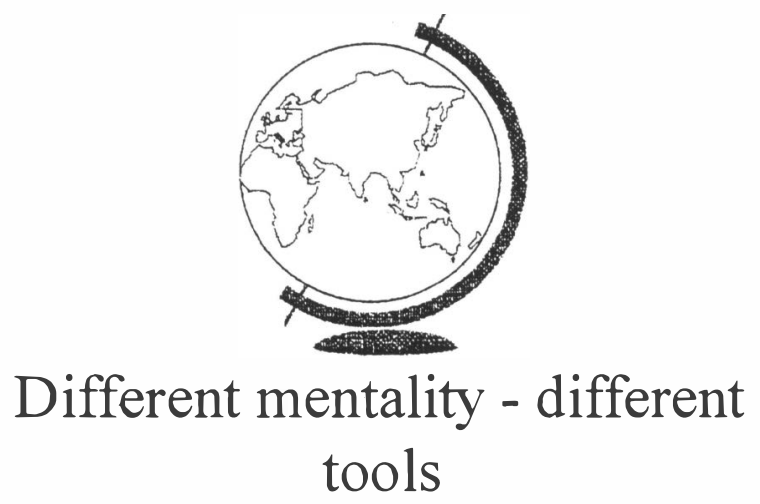

Lithuania - in focus 


\section{Study the country carefully}

$\uparrow$ History \& culture

$\uparrow$ Books \& studies

+ Swedish Trade Councils market information services

+ Internet

+ VISIT LITHUANIA. Spend "the extra day" in the country. LISTEN TO THE PUISS:

\section{Spread the information around and create a network}

$\downarrow$ Visit

- Embasy of Sweden

- Swedish Trade Council

- Lithuanian Development Agency

- Lawyers

- Lithuanian Investment Agency

- Swedish companies

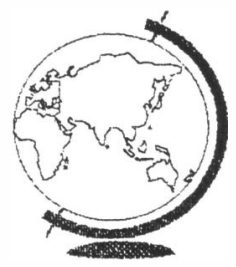




\section{Find reliable local partners}

$\downarrow$ You have a right to choose

+ Establish relations with a potential partner

$\downarrow$ Try to get "up-close and personal" with the potential partner

$\downarrow$ !You are not only doing business together!

\section{Show respect to your business}

\section{partner}

$\downarrow$ Listen to her / him carefully and try to learn everything about the market

+ Use his / her netwoork

+ Try too increase the trust between you and the partner

$\downarrow$ (!) Lithuanians are suspectfull (!)

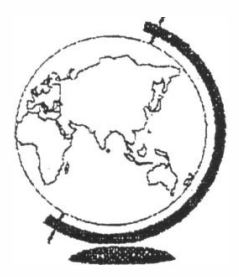




\section{Respect the local conditions}

+ All businness is local

+ Never say "We, in Sweden, do it this way..." (!) You are in Lithuania not to teach, but to do business (!)

$\downarrow$ Learn about "Lithuanian way of doing business"

\section{Use Media}

^ "70\% of lithuanian population strongly belive in media" - BI Research, may 1996

$\downarrow$ Make a possitive impression on journalists

$\uparrow$ Do not "go out"in media too early

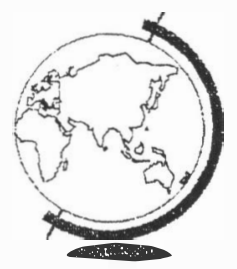




\section{Establish good relations with the Lithuanian autorities}

$\downarrow$ Ministries

- Ministry of Economy

- Ministry of Erropean Affairs

- Bransch Ministries

$\downarrow$ Governmental institutions

$\downarrow$ Agencies

- Lithuanian Delopment Agency

- Lithuanian Investment Department

- Lithuanian Privatisation Agency

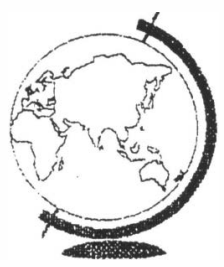

\section{Dont wait - ACT!!!}
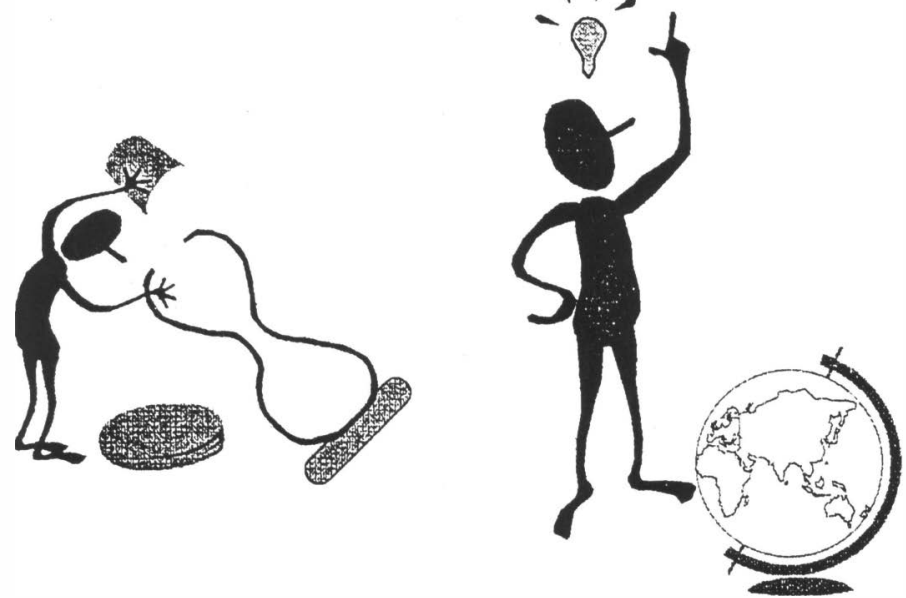


\section{Don't want to get a quick result}

+ Don't give up!

+ Don't be angry!

+ The new establishment allways tacke time!

+ All 3 markets are only 7 years old.
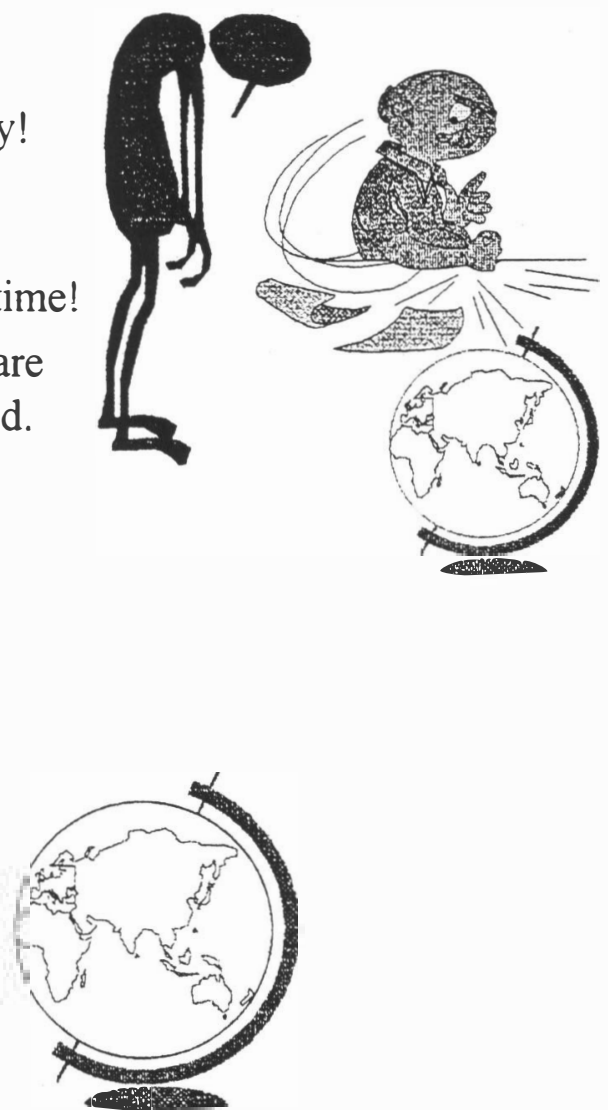

Ask us!

We are "on the spot" to help you! SWEDISH TRADE COUNCIL 


\section{How can you find STC Vilnius}

Embassy of Sweden in Vilnius

Jogailos 8

2600 VILNIUS

Lithuania

tel.: +3702226155

fax: +3702226697

e-mail: mantas.zalatorius@swedishtrade.se

http://ww.swedishtradé.se 